\title{
THE MEMBERSHIP OF THE INDEPENDENT LABOUR PARTY, I904-IO: A SPATIAL AND OCCUPATIONAL ANALYSIS
}

E. P. Thompson expressed succinctly the prevailing orthodoxy about the origins of the Independent Labour Party when he wrote, in his homage to Tom Maguire, that "the ILP grew from bottom up". 1 From what little evidence has been available, it has been argued that the ILP was essentially a provincial party, which was created from the fusion of local political groups concentrated mainly on an axis lying across the North of England. An early report from the General Secretary of the party described Lancashire and Yorkshire as the strongholds of the movement, and subsequent historical accounts have supported this view. ${ }^{2}$

The evidence falls into three categories. In the first place labour historians have often relied on the sparse and often imperfect memoirs of early labour and socialist leaders. While the central figures of the movement have been reticent in their memoirs, very little literature of any kind has emerged from among the ordinary members of the party, and as a result this has often been a poor source. The official papers of the ILP have been generally more satisfactory. The inevitable gaps in the annual reports of the party can be filled to some extent from party newspapers, both local and national. There is a formality, nevertheless, about official transactions which reduces their value. Minute books reveal little about the members. Finally, it is possible to cull some information from a miscellany of other sources; newspapers, electoral statistics, parliamentary debates and reports, and sometimes the memoirs of individuals whose connection

\footnotetext{
1 "Homage to Tom Maguire", in: Essays in Labour History, ed. by A. Briggs and J. Saville (1967), pp. $277 \mathrm{ff}$.

2 Tom Mann, ILP General Secretary's Monthly Report, National Administrative Council minutes, March 1894. See, for example, Joseph Clayton, The Rise and Decline of Socialism in Great Britain (1926), p. 82; P. Poirier, The Advent of the Labour Party (1958), pp. 48-50; H. Pelling, The Origins of the Labour Party, $1880-1900$, 2nd ed. (1965), pp. 158-60; R. E. Dowse, Left in the Centre, The Independent Labour Party, 1893-1940 (1966), pp. 8-9.
} 
with the ILP was tenuous or indirect. The evidence thus gained tends to be fragmentary and no more objective than the information derived from within the party itself.

It is the purpose of the present article to use a new source of information to throw additional light on the character of the ILP during the first decades of the twentieth century, and at the same time to attempt a fuller and more specific examination of the spatial distribution and occupational class of the party's supporters. The Registry of Public Companies holds the files of numerous companies formed either to establish or buy newspapers to support the policies and aims of socialist and labour parties. ${ }^{1}$ Among them is the file of the National Labour Press formed in 1910 by the ILP, to extend the publishing activities of the party.

Its main asset was the capital and goodwill of the Labour Leader Limited, which was itself formed in 1904 to purchase the Labour Leader, the weekly newspaper owned and edited since 1893 by Keir Hardie, and to run the paper as the official organ of the ILP. The Registry file contains an Agreement between the two companies and a Schedule which lists the fully-paid shareholders of the original company, who were credited with deferred ordinary shares in the NLP. ${ }^{2}$ The Schedule is not a complete list of the original shareholders, since 1129 partly-paid shares were forfeited in 1910 and the holders of these are not recorded. The names, addresses, occupations and holding of the transferred shareholders are given in the Schedule. Although the information is not always complete, the list must be

1 Newspaper companies were not the only business ventures in which socialists were involved. Local ILP branches often formed trading companies both to undercut local shopkeepers and to enhance their own funds, e.g., Manchester ILP Trading Society, Bradford and District ILP Trading Society. Other companies were formed to fulfil specific objectives such as purchasing premises, e.g., Socialist Institute Ltd. was formed to buy the Bradford Labour Institute, the Hull Friendly and Trades Societies Club Ltd. was able to borrow money from 48 local labour and trade-union clubs and societies to buy a vacant mechanics' institute; see Labour Leader, 12 December 1896, p. 429; 26 December 1896, p. $453 ; 16$ January 1897 , p. $20 ; 23$ January 1897, p. 31 . Virtually all these companies were formed under the provisions of the Industrial and Provident Societies Acts. Unfortunately, the Registry of Friendly Societies is less useful to historians than the Registry of Public Companies; the statutory returns are less informative and files are only kept for a very short period. See, for example, the file of the Atlas Press Society, which was Keir Hardie's last attempt to organise the Labour Leader as a company around himself, Scottish Record Office, FS5/193, 19 October 1900. For objections to registering a company under Companies Acts, see Labour Leader, 14 July 1900, p. 219.

2 Registry of Public Companies, N 106263. Henceforth the company will be referred to as the Labour Leader Ltd., since one object of this analysis is to examine the original shareholder list. 
regarded as one of the major sources for examining the membership of the ILP on a national basis in the period up to 1914 .

Two other companies whose files are available at the Registry are also discussed. The Borough of Woolwich Labour Representation Newspaper, Publishing and Printing Co. Ltd. was launched in 1904 to take over an established weekly labour newspaper, the Borough of Woolwich Journal, which had been formerly published by the Woolwich and District Trades and Labour Council. ${ }^{1}$ Secondly, the Labour Pioneer Printing and Publishing Co. Ltd. was formed in Merthyr Tydfil in 1907 in order to launch a newspaper, which it did eventually in 1911, a matter of a few months before the company expired. ${ }^{2}$ The Merthyr Pioneer survived, however, and eventually ceased publication in May 1922. The file of each company contains a cumulative list of shareholders given as part of their annual returns to the Registrar of Public Companies, together with balance sheets and occasional items of correspondence. ${ }^{3}$

The files of these local newspaper companies provide some insight into the activity and modus operandi of local Labour groups. More central to the immediate purpose, however, they allow the picture of both the capital structure and of the occupational analysis of the shareholders of the Labour Leader Ltd. to be supplemented at a local level. A basic assumption of the analysis is that the shareholders of two of the companies, the Labour Leader Ltd. and the Merthyr company, were mostly convinced supporters of the ILP. In general, this seems reasonable enough, but several considerations act to increase one's confidence. The shares in the Labour Leader Ltd. were offered to members of the ILP through the Labour Leader itself, and also through branches of the party. It is likely that the men and women who subscribed to shares were the most active or the most fervent supporters of the party. The cost of each share, $£ 1$, might be spread over a number of payments, and while the total cost was still high in relation to average wages among the working class, it cannot

1 Public Record Office, BT/31/17292/81915.

${ }^{2} \mathrm{PRO}, \mathrm{BT} / 31 / 18313 / 96196$.

3 In general, the information contained in company files is standard. There are some variations, however, depending on the type of company involved. Some companies consisted of a handful of directors who were the only shareholders; e.g., Clarion Newspaper Co., PRO, BT/31/31789/42159; Labour Publishing Company, whose directors included Norman Angel, Page Arnot, George Lansbury, G. D. H. Cole and H. N. Brailsford, PRO, BT/31/26290/171318. In neither case does the file contain any balance sheets. In contrast, other companies had large numbers of shareholders and returned their annual balance sheets regularly; e.g., Labour Newspapers Itd. (publishers of the Daily Citizen from 1912 to 1915), PRO, BT/31/119898/20435; see also British Library of Political and Economic Science, Coll. G/1972/1ff. 
be said to be prohibitively high. ${ }^{1}$ No doubt some would-be shareholders were excluded for this reason, but in comparing this source with other sources of ILP support it must be remembered that active participation in labour politics in the late nineteenth century and early twentieth century was, in common with politics in general, a relatively expensive business with constant demands and imprecations on members for money, and no one was investing in the Labour Leader Ltd. in the expectation of a high rate of return or capital gain. The extent of a man's political principles were judged by his readiness to make considerable financial sacrifice as much as by his willingness to advocate a cause in public. It thus seems reasonable to argue that the shareholders of the Labour Leader Ltd. were at least characteristic of the most active section of the ILP, those who regularly attended the weekly meetings of the local branch, readily trudged the streets to distribute free literature or to canvass support for the party's candidates, and, above all, contributed handsomely to the numerous appeals for money to pay for elections, strike-funds, publishing activities, hardship funds and the rest. ${ }^{2}$

The case seems even stronger for the Merthyr company. There was no existing asset in the form of an established newspaper. There was no tradition of labour journalism in the area to vindicate the directors' faith in the venture. Moreover, the ILP was a recent newcomer to South Wales and the position of Keir Hardie as junior MP for Merthyr was tentative. ${ }^{3}$ Subscriptions were thus overwhelmingly

1 The average weekly income of the urban wage-earning family was probably between $25 /-$ and $30 /-$ in 1900 , rising to between $30 /-$ and $35 /-$ in 1914 . See, for example, A. L. Bowley, Wages and Incomes in the United Kingdom since 1860 (1937). Recognising the difficulties many people might have in finding $£ 1$, Keir Hardie offered shares in the Labour Leader in 1900 in instalments of 2/6d with guaranteed three-monthly intervals between instalments and a five-week period of grace for every payment; Labour Leader, 17 March 1900, p. 83b. In fact the prospectus proposed share intervals of only one month; see prospectus attached to Labour Leader, 25 August 1900.

2 In common with most other labour newspapers, the Labour Leader, for instance, published full lists of all contributors to the numerous appeals that were launched in its columns. In 1899 the paper offered scholarships to Ruskin College, Oxford, to those readers who raised the greatest amount of money in the ILP Easter Egg Appeal.

'See, for example, K. O. Morgan, "The Merthyr of Keir Hardie", in: Merthyr Politics: The Making of a Working Class Tradition, ed. by Glanmor Williams (1968). The Merthyr branch of the ILP was one of only five branches founded in Wales up to 1897; Fourth Annual Report of the ILP Conference, 1897, p. 10; ILP News, April 1897. The growth of the ILP in Wales was stimulated by the appointment of Willie Wright as South Wales organiser during the period of the 1898 coal stoppage; H. Pelling, op. cit., p. 180; K. O. Morgan, Wales in British Politics, 1867-1922 (1963), pp. 204-05. 
expressions of goodwill, acts of faith. Few people who did not feel personally committed would have subscribed; it was in no reasonable sense a financial investment although, at the same time, subscribers did not anticipate that they would lose their money altogether.

The connection between the Woolwich company and the local ILP is less clearly established. The Labour Representation Association was an amalgamation of Labour, Lib-Lab and even Liberal interests, and is held to have been the first constituency Labour Party to offer individual membership. ${ }^{1}$ The Woolwich Pioneer had been, however, an ILP newspaper, and the local Woolwich ILP was an important element in the local Labour coalition. The Woolwich shareholder list is useful for comparative purposes and enables us to determine the degree of difference between the specifically ILP shareholders and others who were less clearly members of the ILP.

The primary subject of this analysis, then, is the Labour Leader Ltd. and the light its shareholder list throws on the ILP nationally. The Merthyr and Woolwich companies are taken as indicators of the ILP at a local level or, at the very least, as points of correlation and contrast with the NLP.

\section{SHARE DISTRIBUTION: THE PATTERN OF OWNERSHIP}

While each of the three companies had between 620 and 820 shareholders, the pattern of ownership varied enormously, and this reflects the role and character of the newspapers themselves. The Labour Leader was the official organ of the ILP, but the party itself only held

\section{Table 1: Labour Leader - Share distribution}

$\begin{array}{ccccc}\begin{array}{l}\text { Share } \\ \text { units }\end{array} & \begin{array}{c}\text { Number of } \\ \text { holders }\end{array} & \begin{array}{c}\text { Percentage } \\ \text { of holders }\end{array} & \begin{array}{c}\text { Value of } \\ \text { shares in } £\end{array} & \begin{array}{c}\text { Percentage of } \\ \text { share capital }\end{array} \\ 1 & 400 & 54.3 & 400 & 11.28 \\ 2-4 & 208 & 28.4 & 525 & 14.80 \\ 5 & 68 & 9.0 & 340 & 9.58 \\ 6-11 & 39 & 5.4 & 346 & 9.75 \\ 20-50 & 14 & 1.8 & 391 & 11.02 \\ 100-450 & 9 & 1.1 & 1544 & 43.54 \\ & 738 & 100 & 3546 & 100\end{array}$

1 Paul Thompson, Socialists, Liberals and Labour: The Struggle for London, 1885-1914 (1967), pp. 250-62 ; Fifty Years History of the Woolwich Labour Party, 1903-53, ed. by R. B. Stuckle (1953). 
250 shares in the company, in the name of J. Ramsay MacDonald. ${ }^{x}$ Despite the claim of the company that it would have preferred "to extend the personal interest in the paper by having a larger number of shareholders with small holdings than by a small number with a larger holding", 2 the majority of the company's capital was in fact held by 23 individuals who held, between them, $54.5 \%$ of the shares. Many of these were prominent members of the ILP, including several members of the National Administrative Council. ${ }^{3}$ One of the largest, for example, was T. D. Benson, who was Treasurer of the Party. His 201 shares, the third largest individual shareholding, nevertheless belies his real involvement with the paper. A constant source of financial help to the party in the past, he had been the leading figure in the negotiations for the purchase of the paper from Keir Hardie in 1903-4 raising $£ 1,000$ to acquire the paper and lending the ILP money free of interest in March 1904 to complete the deal. ${ }^{4}$

Other individual shareholders were well-known benefactors of the Labour movement. Edward Carpenter, the ethical socialist and poet, who in 1884 helped to launch Justice, organ of the SDF, with a contribution of $£ 300,{ }^{5}$ contributed $£ 25$ to Labour Leader shares, an appropriate demonstration of the catholicity of his socialist dream. Frederick Pethick-Lawrence, old Etonian and fellow of Trinity College, Cambridge, who bought a controlling interest in the Echo in 1901 in order to oppose the South African War, held 100 shares in the paper, and also subscribed to shares in the Woolwich company. ${ }^{6}$ Joseph Edwards, whose Labour Annuals were the almanacs of the Labour movement, was a substantial shareholder, while among the smaller shareholders was a large number of prominent trade unionists and labour politicians: Pete Curran, Ben Turner, J. G. King, James Holmes, F. W. Jowett, Stanton Coit, G. N. Barnes, W. C. Anderson and numerous others.

The direct involvement of the ILP in the company was small. Only 34 local branches, out of a possible $800,{ }^{7}$ held shares and the total official ILP holding was less than $11.0 \%$ of the total share capital.

1 The instructions of the National Administrative Council had been that the shares be held jointly by W. Field and J. R. MacDonald, but Field's name does not appear in the Register; NAC minutes, 15-16 June 1904.

2 Untitled pamphlet published by the ILP urging members to take up more shares: John Burns Collections, TUC Library, LL 39 (41) 371 (06) 21, 21 April 1905.

3 Including Miss Isabella Ford and Philip Snowden.

4 NAC minutes, 24-26 September and 11 November 1903; 21-23 March 1904.

- Pelling, op. cit., p. 24.

- For Pethick-Lawrence see G. P. Gooch, Historical Surveys and Portraits (1966).

7 R. E. Dowse, op. cit., p. 19. 
Table 2: Labour Leader - Share distribution

\begin{tabular}{lccc} 
Individuals & $\begin{array}{c}\text { Number of } \\
\text { shareholders }\end{array}$ & $\begin{array}{c}\text { Value of } \\
\text { shares in } £\end{array}$ & $\begin{array}{c}\text { Percentage of } \\
\text { share capital }\end{array}$ \\
ILP branches & 687 & 3096 & 87.3 \\
National ILP & 34 & 138 & 3.9 \\
Other institutions & 1 & 250 & 7.0 \\
& 16 & 62 & 1.8 \\
\hline & 738 & 3546 & 100
\end{tabular}

While it is perfectly understandable that the national party might have been reluctant to commit more money to the enterprise than was absolutely necessary, the failure of the local branches to subscribe more generously must have been disappointing to the organisers of the prospectus of 1904, and those that did apply only subscribed the smallest sums. Only 14 branches held 5 shares or more, and the average for the others was 3 shares each. The other clubs and institutional holders were a combination of trade-union branches and miscellaneous socialist groups, six of which are unidentifiable since only the secretary's name was given in the shareholder list. Their average shareholding of four shares is the same as the overall average for ILP branches. In a sense, then, the degree of support for the Labour Leader was no greater among ILP branches than among societies and tradeunion branches with no direct link with the party itself. Indeed, excluding the national ILP itself, three of the five largest institutional shareholders were trade-union branches in Doncaster, Milnsbridge and Falkirk.

The ILP branches that did subscribe were concentrated mainly in North and North-West England. The average shareholding was, in fact, significantly higher among ILP branches in the North-West than elsewhere (6 shares). Some areas were poorly represented. There were 36 branches in Wales in 1906 and 58 by 1912, of which only one, Aberdare, was a shareholder of the Labour Leader, while out of branches recorded in the Midlands in that period only two, at Stapleford and Glossop, were shareholders. ${ }^{1}$ Many ILP branches were, in any case, short-lived, but a certain number were very durable and several of these appear in the NLP list, among them Colne, Nelson, Huddersfield, Darlington and Bradford. But a great many of the missing branches were strongholds of the ILP in its first difficult years and bastions of its traditions in later years: Keighley, Liverpool, Edinburgh,

1 Thirteenth Annual Report of the ILP Conference, 1906; 19th Annual Report of the ILP Conference, 1912. 


\section{Table 3: Labour Leader - Geographical distribution of ILP branches holding shares}

No $\begin{gathered}\% \text { of ILP } \\ \text { branches hold- } \\ \text { ing shares }\end{gathered} \quad \begin{gathered}\text { Value of } \\ \text { shares in } £\end{gathered} \quad \begin{gathered}\% \text { of ILP } \\ \text { holding }\end{gathered}$

London \& Home

Counties

East Midlands

Lancashire \& Cheshire

Yorkshire

North of England

Scotland

Wales

\begin{tabular}{rrrr}
4 & 11.8 & 19 & 13.8 \\
2 & 5.9 & 8 & 5.8 \\
10 & 29.4 & 59 & 42.8 \\
8 & 23.5 & 25 & 18.1 \\
4 & 11.8 & 12 & 8.7 \\
5 & 14.7 & 13 & 9.4 \\
1 & 2.9 & 2 & 1.4 \\
\hline 34 & 100 & 138 & 100
\end{tabular}

Musselburgh, Nottingham, Hull, Barrow, Leeds, Bolton, Halifax, Sunderland and Southampton. Each of these branches had issued its own newspaper at various times between 1895 and 1905, but none seemed to show an official interest in the central organ of the party after $1904 .^{1}$

The distribution of individual shareholders corresponds fairly closely to the distribution of subscribing branches. Over half came from the North and North-West, with Yorkshire providing the largest number. Within that county, however, the shareholders were evenly distributed among the larger towns with Bradford, the birthplace of the ILP, supplying only 20 shareholders. Within Lancashire there was a similar pattern with Manchester supplying 17 and Liverpool 9 shareholders, and 86 distributed among the smaller towns. The Scottish distribution was more uneven. Glasgow provided 45, or almost half the Scottish shareholders, Edinburgh 11 and all other Scottish areas 41. In Wales, the majority of shareholders came from the industrial South and only 5 from other parts of the principality.

Many of the individual shareholders would have been members of branches which themselves subscribed to shares. A relatively large number of shareholders came from Doncaster, Bradford, Huddersfield, Stockton, Glasgow, Ashton, Nelson and Colne, where local ILP branches were also shareholders. There are no instances of ILP branches taking up shares when no individuals from the same area also subscribed, whereas there are large clusters of individual share-

1 These branches produced between them 18 different newspapers from 1895 to 1905. See my "Local Newspapers of the Independent Labour Party, 1893-1906", in: Bulletin of the Society for the Study of Labour History, Nos 28-29 (1974). 
Table 4: Labour Leader-Geographical distribution of shareholders

\begin{tabular}{lrrrrrr} 
& \multicolumn{2}{c}{$\begin{array}{l}\text { Individual } \\
\text { shareholders }\end{array}$} & \multicolumn{2}{c}{ IL P branches } & Other clubs \\
& No & $\%$ & No & $\%$ & No & $\%$ \\
London & 59 & 8.6 & 4 & 11.8 & 1 & 5.9 \\
Home Counties & 23 & 3.3 & - & & - & \\
East Anglia & 10 & 1.5 & - & & - & \\
Central Region & 12 & 1.7 & - & & - & \\
Wessex & 10 & 1.5 & - & & - & \\
West Country & 22 & 3.2 & - & & - & \\
West Midlands & 23 & 3.3 & - & & - & \\
East Midlands & 27 & 3.9 & 2 & 5.9 & 2 & 11.7 \\
Lancs. \& Cheshire & 129 & 18.8 & 10 & 29.4 & 2 & 11.7 \\
Yorkshire & 156 & 22.7 & 8 & 23.5 & 6 & 35.3 \\
North of England & 68 & 9.9 & 4 & 11.8 & 3 & 17.6 \\
Scotland & 92 & 13.4 & 5 & 14.7 & 2 & 11.7 \\
Wales & 33 & 4.8 & 1 & 2.9 & 1 & 5.9 \\
Overseas & 7 & 1.0 & - & & - & \\
No address given & 16 & 2.3 & & & & \\
& 687 & 100 & 34 & 100 & 17 & 100
\end{tabular}

holders in localities where the local ILP did not become a shareholder: Wakefield, Newcastle, Keighley, Littleboro, Gateshead etc. This seems to suggest that the initiative for buying shares came from individual shareholders, who then persuaded their branches to subscribe too.

The central question is, to what extent can the shareholders of the Labour Leader Ltd. be taken as characteristic of the membership of the ILP? Is it possible, perhaps, to define the shareholders as the core of the party? The historical problem has been to decide if the "true" membership of a political party includes those who regularly support the aims and electoral campaigns of the party, without actually subscribing to its funds or even taking out membership. In many areas of Britain it was not possible to maintain dir ect contact with the ILP. The ILP fought elections only in a limited number of districts, and sympathisers of the party outside these areas found it difficult to express their political sympathies in a direct way. The fact that so few individual shareholders of the Labour Leader Ltd. came from areas such as the West Country or East Anglia or, indeed, the Midlands, might suggest that support for the ILP was weak in these areas. Of course, it is not quite as simple as that. The information about the shareholders of the Labour Leader Ltd. is incomplete. Over 1000 shares were forfeited in 1910, and it is highly probable that the bulk of these 
were held in single units. Many of these shareholders may well have come from areas which, in the final list, were poorly represented. What can be adduced from this source, therefore, are the areas of strength of the ILP; the areas of weakness are less obvious. The strongholds of the ILP which emerge in this source are precisely those which predominated a decade and more earlier. In other words, if this particular source is an accurate reflection of the distribution of the ILP membership generally, then there was no manifest change in that distribution between 1893 and 1910 . The party remained essentially a provincial party with its areas of greatest strength either side of an axis from the Humber to Merseyside and with pockets of support elsewhere, notably in Scotland, London and the South Wales coalfield.

A relatively small proportion of the members of the ILP subscribed to shares in the company. The total of 687 individual shareholders, or 1,700 if one includes the estimated number of individuals whose shares were forfeited, is substantially less than the estimates given for party membership at this time, which vary between 7,000 and $22,000 .{ }^{1}$ Evidently a large number of members were transient; so much depended on the administrative efficiency of branch officials in obtaining and then transmitting to the national headquarters the monthly subscriptions that it is likely that many people were not given the opportunity of remaining members for long. Others may well have drifted in and out of the party. A distinction can be drawn in any case between different types of members, the criterion being their relative levels of activity and the scope of their interest. A large number, for instance, may well have been keen supporters of the local branch without taking an active interest in the party's national activities. The Labour Leader share issue was manifestly important to the national party, and the fact that so few members subscribed, even though the register was open effectively from 1904 to 1910, suggests that the hard core of those who might be termed "national ILPers" was no more than 1,700 , and quite probably much less.

An analysis of the share distribution of the Woolwich and Merthyr companies reveals some interesting points of contrast. The Merthyr company had the largest number of shareholders and yet was held weakest in capital structure. $72.5 \%$ of its share capital was held in

1 Philip Poirier distinguishes between 7,000 "paying" members and a "total" membership of 20,000; The Advent of the Labour Party, p. 49. See also Dowse, op. cit., p. 12. The ILP claimed a membership of 14,000; Labour Party Foundation Conference and Annual Conference Reports (Hammersmith Reprints, 1967), p. 198. 
Table 5: Merthyr Pioneer - Share distribution

$\begin{array}{ccccc}\begin{array}{c}\text { Share } \\ \text { units }\end{array} & \begin{array}{c}\text { Number of } \\ \text { holders }\end{array} & \begin{array}{c}\text { Percentage } \\ \text { of holders }\end{array} & \begin{array}{c}\text { Value of } \\ \text { shares in } £\end{array} & \begin{array}{c}\text { Percentage of } \\ \text { share capital }\end{array} \\ 1 & 741 & 91.1 & 741 & 72.5 \\ 2 & 36 & 4.4 & 72 & 7.1 \\ 3 & 10 & 1.2 & 30 & 2.9 \\ 4 & 3 & 0.4 & 12 & 1.2 \\ 5 & 21 & 2.7 & 105 & 10.3 \\ 10 & 1 & 0.1 & 10 & 1.0 \\ 50 & 1 & 0.1 & 50 & 5.0 \\ & -13 & 100 & 1020 & 100\end{array}$

single units, and less than $17 \%$ of the entire capital was held in units of 5 and over. The largest single shareholder, with 50 shares, was ironically enough D. A. Thomas, the Liberal Senior Member for Merthyr and owner of the Cambrian Collieries. ${ }^{1}$ The distribution of shares reflects the weakness of the company. It took four years for the company to launch its newspaper, by which time a great deal of the capital had been dissipated, and in 1912, when financial problems became acute, the directors were obliged to negotiate a mortgage. Within a month the new creditors applied for the appointment of a receiver, and the original company was wound up. It was the lack of working capital which, more than anything else, contributed to the company's weakness. Out of 5000 issued shares only 1020 were ever taken up, and the company did not receive all the money for these. The directors were more enthusiastic than proficient and found their new roles something of a burden. ${ }^{2}$ In relative and absolute terms, however, the Merthyr company attracted more support from individuals, however little money they actually contributed, than did the Labour Leader. None of the shareholders came from outside the Merthyr area, and the fact that the company could attract as many shareholders as it did testifies to the considerable vigour of the labour movement, and the ILP in particular, in the Merthyr area.

In complete contrast to Merthyr, the Woolwich company gained a number of wealthy and open-handed patrons. There was a flourishing tradition of labour journalism in Woolwich, and the Woolwich Pioneer

$1 \mathrm{~K}$. O. Morgan describes his career as "contradictory". "The most hated coalowner in South Wales, he was the friendly associate of Keir Hardie." "D. A. Thomas: The Industrialist as Politician", in: Glamorgan Historian, III (1966), ed. by Stewart Williams, esp. pp. 45-50.

2 See, for example, the letter of apology to the Registrar of Public Companies from the evidently harassed Secretary, PRO, BT/31/18313/96196. 


\section{Table 6: Woolwich Pioneer-Share distribution}

$\begin{array}{lcccc}\begin{array}{l}\text { Share } \\ \text { units }\end{array} & \begin{array}{c}\text { Number of } \\ \text { holders }\end{array} & \begin{array}{c}\text { Percentage } \\ \text { of holders }\end{array} & \begin{array}{c}\text { Value of } \\ \text { shares in } £\end{array} & \begin{array}{c}\text { Percentage of } \\ \text { share capital }\end{array} \\ 1 & 422 & 66.35 & 422 & 9.6 \\ 2-4 & 106 & 16.76 & 239 & 5.4 \\ 5 & 51 & 8.01 & 255 & 5.8 \\ 8-19 & 33 & 5.18 & 328 & 7.5 \\ 20-100 & 22 & 3.45 & 1150 & 26.2 \\ 1000 & 2 & 0.31 & 2000 & 45.5 \\ & 636 & 100 & 4394 & 100\end{array}$

grew out of an earlier journal, the Woolwich and District Labour Notes, which was launched in November 1898. ${ }^{1}$ The response to the prospectus of 1904 was good, but the company increasingly came to depend on the generosity of a small number of benefactors. $71.7 \%$ of the company was owned by 24 individuals who invested $£ 3150$, but two of these in particular owned nearly half the entire issued capital. Frederick Pethick-Lawrence, who contributed large sums of money to Labour newspapers including the Labour Leader, invested $£ 1000$ in the Woolwich company, but it was Joseph Fels the soap manufacturer and disciple of Henry George, and sponsor of Lenin at this time, who made the greatest financial contribution. ${ }^{2}$ Apart from his initial investment of $£ 1000$ in share capital, Fels also donated around $£ 1000$ a year towards the running costs of the paper. ${ }^{3}$ And there were others who made considerable sacrifices in the interest of the paper. One shareholder, Charles Grinling, is said to have devoted his entire life savings to the paper.4 Among the larger shareholders were May Tennant, the eminent social reformer and wife of the Liberal Secretary of State for Scotland, Harold Tennant, and G. P. Gooch, the author and historian. More than the Merthyr Pioneer it was a paper that attracted recognisable establishment figures as well as ordinary working men and women. The Rector of Woolwich and the Dean of Durham were among several ministers of religion who contributed handsomely

1 The Borough of Woolwich Labour Pioneer began as the Woolwich and District Labour Notes, first published in November 1898 by the Woolwich and Plumstead ILP. It discontinued in December 1899 but resumed publication as the Borough of Woolwich Labour Journal in October 1901, published by the Trades Council, and the title Pioneer was assumed by the new company in 1904.

2 William Stewart, Keir Hardie (1921), p. 274; Paul Thompson, op. cit., p. 262 For Fels's sponsorship of Lenin, see A. P. Dudden and T. H. von Laue, "The RSDLP and Joseph Fels", in: American Historical Review, LXI (1955-56).

3 Thompson, op. cit., p. 262.

4 Ibid., p. 262. Grinling was listed as holding 100 shares. 
to the paper's funds. Seebohm Rowntree, the philanthropist and sociologist, invested $£ 50$ in the paper although he actually lived in York. Altogether $85 \%$ of the shares were held in blocks of $£ .5$ or more, including 7 shareholders who invested at least $£ 100$. Like Fels, their support of the paper often went much further than simply contributing to the issued share capital. Between 1905 and 1914 a group of supporters, including Fels, wrote off $£ 3271$ of the paper's short-term debts, arranged to relieve the paper of $£ 7000$ of liabilities, and eventually agreed to write down the issued share capital of the company by $19 / 6 \mathrm{~d}$ in the pound, their own holdings being the main casualties. ${ }^{1}$ The Woolwich company, for one reason or another, was an expensive enterprise, and unlike the Labour Leader after 1910 it did not have a publishing house to subsidise it. Despite all the financial help given it over the years, the paper eventually floundered in 1922, leaving the local Labour Party with accumulated liabilities of over $£ 4000$, which were barely paid off a decade later. ${ }^{2}$

There were manifest differences between the Merthyr and Woolwich companies, but they had one thing in common. The number of shareholders they attracted suggests that, in contrast to a national paper like the Labour Leader, a local labour newspaper company enjoyed greater support from individual supporters of the labour movement. What the Merthyr company lacked in wealth it made up in enthusiasm, while the Woolwich company inspired its supporters to great heights of generosity. They were both essentially local newspapers, and no doubt generated a greater degree of enthusiasm and commitment among local people than a national newspaper might. Part of the explanation must be, however, that neither newspaper was overtly tied to a particular section of the labour movement; the Woolwich Pioneer, in particular, was the expression of a broadlybased socialism, which embraced fringes of the Liberal Party as much as the ILP itself. The contrast between the level of support for these newspapers and the Labour Leader, which was explicitly the organ of one particular section within the Labour movement, reinforces the impression that support for the ILP as a national party was thinly distributed.

\section{OCCUPATIONAL CLASS DISTRIBUTION}

Two problems arise in analysing the occupations of shareholders in the three companies. Occupational descriptions are self-allocated and unstandardised, and the information is often incomplete. The

1 Company prospectus, 19 March 1914, BT/31/17292/81915.

2 See Fifty Years History of the Woolwich Labour Party, op. cit. 
quality of information regarding occupations has often been a major imponderable for social historians or social scientists and even for Census enumerators themselves.

"A worker may quite correctly describe himself or herself as an 'embroidery worker' but the difference between hand and machine embroidery is as great as between a monk who transcribes the Gospels and the machine operator who prints them."1

The shareholder lists provide numerous examples of this kind of ambiguity, but it is only when one attempts to recast the various occupations into occupational groups that the ambiguities pose an obstacle to precise quantification.

A simple occupational categorization has been employed, therefore, whose validity is not contingent upon precise information. It consists of an elaboration of the five-class system originally used in the Census of 1911, and provides broad distinctions between professional, proprietorial, managerial, clerical, supervisory and various manual groups. ${ }^{2}$ Each of these groups is capable to sub-division, but this depends on additional information, which in this case is not available. At the higher registers, occupational descriptions are reasonably clear. Hence the professions are, in this respect, unambiguous. Definitions

\section{Table 7: Occupational class structure}

Group Description

IA Higher professional

IB Lower professional

IIA Proprietors

IIB Managers, higher administrative

III Clerical

IV Supervisors, foremen

V Skilled manual

VI Semi-skilled manual

VII Unskilled manual
Registrar General equivalent (1911)

1 Dr Schwartz-Lyon, System of Classification (International Labour Organization), quoted in A. M. Carr-Saunders and D. Caradog Jones, A Survey of the Social Structure of England and Wales (1927), p. 35. For further discussion of this particular problem see ibid., pp. 33-47.

2 For fuller discussion of this system see Guy Routh, Occupation and Pay in Great Britain, 1906-60 (National Institute of Economic and Social Research, 1965), ch. 1 and Appendix A. 
become more blurred as one descends the scale. The descriptions "tailor", "baker" and "grocer" can be either proprietorial or craft. The title "manager" implies a wide range of functions, at one end of which is an occupation with considerable power and responsibility, and at the other an occupation which is little more than supervisory. The problem becomes especially acute when dealing with degrees of manual skill. Strictly speaking a skilled manual worker is a specialist, but the ambiguities lie in terms which in reality do little more than identify the industry within which an individual is employed. Hence a "weaver" might be skilled or semi-skilled and the term "engineer" is fraught with ambiguity. ${ }^{1}$

Resolving such ambiguities becomes important if the purpose of assigning occupations into groups is to draw inferences about their social status. An occupational class structure is not explicitly a social hierarchy, but it is heuristic and permits some guidance towards assessing social class. At the same time a system of groups which is based upon the simplest assessment of function, and which does not take into account factors such as degrees of independence, scale of function or income, cannot provide an entirely satisfactory guide to social status. ${ }^{2}$ The system employed in this analysis is no more than a crude, general but workable categorisation, which enables the historian confronted by limited information nevertheless to assemble that information into useful descriptive quantities.

The incompleteness of the information poses different problems. The Merthyr list gives an occupational description of some sort for $99.1 \%$ of the shareholders. The occupations of over $16 \%$ of the Woolwich shareholders, however, are not given (henceforth referred to as "unidentified"), while $39.1 \%$ of the Labour Leader shareholders are unidentified. It is statistically valid to assume $a$ priori that unidentified shareholders would be distributed among the various occupational

\footnotetext{
1 The term "miner" has, for example, posed special difficulties for sociologists. In the Hall-Jones system of grading, miners were assigned to group VI (semiskilled manual), while Young and Willmott regraded them to group V (skilled); J. Hall and D. Caradog Jones, "The Social Grading of Occupations", in: British Journal of Sociology, I (1950); M. Young and P. Wilmott," "Social Grading by Manual Workers", ibid., VII (1956).

2See, for example, T. H. Marshall, "The Nature and determinants of social status", in: Year Book of Education, 1953; C. A. Moser and J. R. Hall, "The Social Grading of Occupations", in: Social Mobility in Britain, ed. by D. V. Glass (1954); Irving Kraus, "Some perspectives on social stratification and social class", in: Sociological Review, XV (1967). For a useful survey of the subject see Ioan Davies, Social Mobility and Political Change (1970). An interesting departure from the conventional systems is offered in R. S. Neale, Class and Ideology in the Nineteenth Century (1972), ch. 1.
} 
groups in the same proportions as those already identified. Clearly there are pitfalls here, especially when less than two-thirds of the shareholders are identified as in the case of the Labour Leader Ltd. Two additional procedures have been taken in the case of that company, to guard against possible error. In the first place an additional computation has been made after redistributing the unidentified shareholders found in each area of Britain (see Table 9) according to the occupational distribution observed among the identified shareholders in that area, and the results of that computation are presented in parentheses in the third column of Table 8. Secondly, in the case of the smaller occupational groups in both the Labour Leader Ltd. and the Woolwich company lists it has been supposed that there is a strong likelihood that none of the unidentified shareholders would have in reality belonged to those particular groups. This simply involves comparing the observed numbers and relative proportions of such groups with the estimated numbers and proportions of other groups in order to test the statistical significance of the former groups. ${ }^{1}$

Since the Labour Leader was a national newspaper it is possible to correlate the occupational distribution of its shareholders with the British distribution. The group which shows the highest significant difference from its nationally observed proportion is the higher professional. It is seven times greater than the national distribution, and even if all the unidentified shareholders were included and no more members of this group were found, it would still be proportionately four times more numerous than nationally. This is perhaps unexpected because, although it has been generally held that the early political labour movement was fostered by enlightened members of the professions, it is the "intelligensia" which is usually referred to. The shareholders of the Labour Leader Ltd., however, included a wide range of professions including lawyers, accountants, architects, surveyors and medical practitioners. Teachers, on the other hand, formed the overwhelming bulk of group IB, and this does enhance the significance of that particular group. Taken together the professional groups are the largest gi oup relative to their national proportions in this shareholder list.

The second largest in relative terms is the clerical group, followed closely by the supervisors and foremen. Some historical analyses have suggested that the differences in the class and work situations of clerks and manual workers, the two branches of the "propertyless" section

1 The Pearson Chi-Square test has been employed to test "goodness-of-fit" in all cases. The result is highly significant (Probability $>0.001$ ); see W. L. Holt, Statistics (1969). 


\section{Table 8: Labour Leader - Occupational distribution by groups}

\begin{tabular}{|c|c|c|c|c|c|c|}
\hline \multirow[t]{2}{*}{ Group } & \multirow{2}{*}{$\begin{array}{c}\text { Great } \\
\text { Britain } \\
\% *\end{array}$} & \multicolumn{3}{|c|}{ Labour Leader } & \multicolumn{2}{|c|}{$\begin{array}{c}\text { Relative } \\
\text { distribution }\end{array}$} \\
\hline & & No & \multicolumn{2}{|c|}{$\%$ of total ${ }^{* *}$} & $\mathrm{~GB}^{* * *}$ & LL \\
\hline IA & 1.00 & 25 & 7.1 & $(6.7)$ & 4 & 25 \\
\hline IB & 3.05 & 12 & 3.4 & $(3.0)$ & 11 & 12 \\
\hline IIA & 6.71 & 40 & 11.4 & $(12.2)$ & 24 & 40 \\
\hline IIB & 3.43 & 10 & 2.8 & $(2.7)^{\prime}$ & 12 & 10 \\
\hline III & 4.84 & 54 & 15.4 & (15.3) & 17 & 54 \\
\hline IV & 1.29 & 20 & 5.7 & $(6.25)$ & 5 & 20 \\
\hline V & 30.56 & 159 & 45.3 & (45.1) & 106 & 159 \\
\hline VI & 39.48 & 19 & 5.4 & $(5.3)^{\prime}$ & 138 & 19 \\
\hline \multirow[t]{8}{*}{ VII } & 9.63 & 12 & 3.4 & $(3.5)$ & 34 & 12 \\
\hline & 100 & 351 & 100 & $(100)$ & 351 & 351 \\
\hline & & & & No $\%$ & of total & \\
\hline & & \multirow{4}{*}{\multicolumn{2}{|c|}{$\begin{array}{l}\text { Total identified } \\
\text { Unoccupied females } \\
\text { Clubs, institutions } \\
\text { Unidentified males }\end{array}$}} & 351 & 47.7 & \\
\hline & & & & 47 & 6.3 & \\
\hline & & & & 51 & 6.9 & \\
\hline & & & & 289 & 39.1 & \\
\hline & & & & 738 & 100 & \\
\hline
\end{tabular}

* Figures are taken from Guy Routh, Occupation and Pay in Great Britain 1906-60 (Cambridge, 1965), and are based on the Census returns, 1911.

** Percentages in parentheses are determined by redistributing the unidentified in each area according to the occupational distribution observed among the identified in each area (see Table 9).

*** The absolute numbers are obtained by redistributing a 351 sample (the Labour Leader total) according to the percentage distribution in the first column.

of society, have produced a tardy class consciousness among the former. ${ }^{1}$ If participation in the ILP is any indication of class consciousness, then the figures revealed in the shareholder list would tend to contradict this view and suggest that clerks were a particularly active political group.

Two other groups, employers and proprietors, both in IIA, on the one hand and skilled manual workers on the other, are also well represented. The total quoted for the former group, however, is enhanced by the inclusion of 9 grocers and tailors who were assumed to be self-employed. Removing these alters the picture considerably. Semi-skilled and unskilled workers are on the other hand very poorly represented. While this may in part be due to the particular assigna-

1 David Lockwood, The Black-Coated Worker: A Study in Class Consciousness (1958). 
tions made in this analysis, the fact remains that semi-skilled workers, in particular, are notably absent from the list. Lower-paid workers may have found it more difficult to find the money to buy shares, but it is equally likely that they would have found it difficult to participate fully in a political movement that required regular financial contributions from its members as an earnest of their commitment.

The geographical distribution of occupational groups reveals that groups IA and IB were strongest, in relative terms, in the South of England, while groups III, IV and VI were strongest in the North. Group V, however, emerges dominant in every area, but particularly so in Yorkshire, Lancashire, Durham and Scotland. Beyond this, it cannot be said that any area showed significant occupational characteristics and it follows that the ILP tended to attract the same kind of people in every area.

Both the Merthyr and Woolwich figures show a significant drop in the proportion of higher professionals compared with the Labour Leader Ltd., but a higher proportion of lower professionals. This latter is partly accounted for by teachers, who provide the majority of group IB in Woolwich and all 36 subscribers from this category in Merthyr. The proportion of ministers of religion increased too, especially in Woolwich. Out of 55 shareholders with shares of $£ 10$ and more in the Woolwich company, 6 are ministers. A higher proportion of class IIA in both newspapers are tailors, drapers and grocers than

\section{Table 9: Labour Leader-Geographical distribution of occupational classes}

\begin{tabular}{|c|c|c|c|c|c|c|c|c|c|c|c|c|}
\hline & \multicolumn{5}{|c|}{ Occupational } & \multicolumn{2}{|c|}{ classes } & & & \multirow{2}{*}{ Uniden- } & \multirow[t]{2}{*}{ Female } & \multirow[t]{2}{*}{ Tot } \\
\hline & IA & IB & IIA & IIB & III & IV & $\mathrm{V}$ & VI & VII & & & \\
\hline London & 5 & 3 & 3 & & 5 & 2 & 6 & 4 & 2 & 24 & 5 & 59 \\
\hline Home Counties & 1 & & 1 & & 3 & & 4 & & & 13 & 1 & 23 \\
\hline East Anglia & 1 & & 1 & & & & & 2 & & 6 & & 10 \\
\hline Central Region & & & 1 & 1 & & & 2 & & 1 & 5 & 2 & 12 \\
\hline Wessex & & 1 & 1 & 1 & & & 2 & & & 5 & & 10 \\
\hline West Country & & & 1 & & 1 & 1 & 3 & & 5 & 8 & 3 & 22 \\
\hline West Midlands & & & & & 4 & 2 & 5 & & & 11 & 1 & 23 \\
\hline East Midlands & 1 & & 4 & & 1 & 2 & 11 & & & 8 & & 27 \\
\hline Lancs. \& Cheshire & 6 & 2 & 11 & 3 & 15 & 1 & 24 & 1 & 1 & 53 & 12 & 129 \\
\hline Yorkshire & 4 & 5 & 6 & 2 & 10 & 9 & 37 & 8 & 1 & 56 & 18 & 156 \\
\hline North of England & 1 & & 4 & & 4 & & 29 & 2 & 1 & 26 & 1 & 68 \\
\hline Scotland & 2 & & 3 & 1 & 6 & 1 & 23 & 1 & 1 & 52 & 2 & 92 \\
\hline Wales & 1 & 1 & 3 & 2 & 3 & 2 & 12 & 1 & & 6 & 2 & 33 \\
\hline Overseas & 1 & & & & 1 & & 1 & & & 4 & & 7 \\
\hline No address given & 2 & & 1 & & 1 & & & & & 12 & & 16 \\
\hline & 25 & 12 & 40 & 10 & 54 & 20 & 159 & 19 & 12 & 289 & 47 & 587 \\
\hline
\end{tabular}


Table 10: Woolwich Pioneer and Merthyr Pioneer

\begin{tabular}{|c|c|c|c|c|c|c|}
\hline \multirow[t]{2}{*}{ Group } & \multicolumn{2}{|c|}{$\begin{array}{l}\text { Woolwich } \\
\text { Pioneer }\end{array}$} & \multicolumn{2}{|c|}{$\begin{array}{l}\text { Merthyr } \\
\text { Pioneer }\end{array}$} & \multicolumn{2}{|c|}{$\begin{array}{c}\text { National Labour } \\
\text { Press }\end{array}$} \\
\hline & No & $\begin{array}{l}\text { As } \% \text { of } \\
\text { total }\end{array}$ & No & $\begin{array}{l}\text { As } \% \text { of } \\
\text { total }\end{array}$ & No & $\begin{array}{l}\text { As } \% \text { of } \\
\text { total }\end{array}$ \\
\hline IA & 24 & 4.82 & 12 & 1.52 & 25 & 7.1 \\
\hline IB & 27 & 5.42 & 36 & 4.58 & 12 & 3.4 \\
\hline IIA & 37 & 7.43 & 58 & 7.38 & 40 & 11.4 \\
\hline IIB & 6 & 1.20 & 0 & - & 10 & 2.8 \\
\hline III & 39 & 7.83 & 54 & 6.87 & 54 & 15.4 \\
\hline IV & 18 & 3.61 & 50 & 6.36 & 20 & 5.7 \\
\hline $\mathrm{V}$ & 293 & 58.83 & 531 & 67.64 & 159 & 45.3 \\
\hline VI & 16 & 3.21 & 37 & 4.71 & 19 & 5.4 \\
\hline \multirow[t]{2}{*}{ VII } & 38 & 7.63 & 7 & 0.89 & 12 & 3.4 \\
\hline & 498 & 100 & 785 & 100 & 351 & 100 \\
\hline \multirow{6}{*}{$\begin{array}{l}\text { Total } \\
\text { identified } \\
\text { Unoccupied } \\
\text { females } \\
\text { Clubs and } \\
\text { institutions } \\
\text { Unidentified } \\
\text { males }\end{array}$} & 498 & 78.3 & 785 & 96.5 & 351 & 47.7 \\
\hline & 29 & 4.5 & 17 & 2.1 & 47 & 6.3 \\
\hline & & & & 05 & & \\
\hline & 1 & 0.1 & 4 & 0.2 & 31 & 0.9 \\
\hline & 108 & 17.0 & 7 & 0.9 & 289 & 39.1 \\
\hline & 636 & 100 & 813 & 100 & 738 & 100 \\
\hline
\end{tabular}

is the case in the Labour Leader Ltd., ${ }^{1}$ while the class as a whole is very much smaller than in the latter. If it could be established that the people in question were in fact proprietors, it would be a significant revelation of the extent of support for local Labour parties by small businessmen and shopkeepers. Clerks, on the other hand, are less well represented than in the Labour Leader Ltd., and this might suggest that while clerks were prepared to identify themselves with a remote national Labour party and newspaper, they were less inclined to reveal their colours at a local level.

Certain occupational features of both shareholder lists reflect the particular occupational characteristics of the areas themselves. The overwhelming majority of supervisors and skilled manual workers in the Merthyr list came from the mining industry; checkweighers on the one hand and "miners" on the other hand. In Woolwich, it is the engineering industry that predominates with "engineers" and "ma-

1 Labour Leader: 9 (2.2\% of all shareholders); Woolwich Pioneer: $23(4.5 \%)$; Merthyr Pioneer: $42(5.4 \%)$. 
chinists" accounting for $41.7 \%$ of the total number of shareholders. In both cases, however, it must be pointed out that it is impossible to ascertain what precise levels of skills were involved. Only one thing is clear: unskilled manual workers are much easier to identify and in both lists they are poorly represented, especially in Merthyr. This might be partly explained in the latter case by the prospects of the enterprise. The Merthyr company was evidently a riskier business than its Woolwich counterpart, and the deterrent effect on low-paid workers correspondingly greater. While no one expected to reap capital gains from this kind of investment, subscribers did not want to throw their money away.

It is virtually impossible to correlate the occupation distributions of the Woolwich and Merthyr shareholders with the national distribution. A considerable percentage of the shareholders of both companies lived in neighbouring areas, Plumstead, Eltham and Abbey Wood on the one hand, and Aberdare on the other. Hence it is impossible to decide on a correct apportionment of the census returns of each area to determine how typical or untypical the shareholders were of the local population.

It becomes clear that the local newspapers attracted more workingclass support, especially among the skilled manual workers, than the Labour Leader did, and less from the "middle class". It is also evident that the most substantial financial support tended to come from the professional group and that, moreover, the degree of relative support declined at lower points in the occupational hierarchy. In the case of Woolwich, the statistics for group IA and IIA are distorted by the inclusion of the two very large individual shareholdings of PethickLawrence and Joseph Fels, but this does not invalidate the conclusion.

\section{CONCLUSION}

The limitations of the shareholder lists for a sociological analysis of the ILP in the period 1904-11 are clear. The information is incomplete, the occupational designations frustratingly imprecise, and in some cases possibly fictitious, ${ }^{1}$ and the populations are small. Even the application of statistical validations leaves considerable room for

1 Included in the category of "unidentified" are those shareholders for whom no occupational entry is made at all, and also those who have described themselves as "gentleman" or "artisan", although wherever possible the individual in question has been allocated to a definite occupational group; hence G. P. Gooch, who describes himself in the Woolwich list as an "artisan", was allocated to group IA, and Pete Curran, who adopts the description "agitator" for himself, is allocated to the IIB. In some cases, admittedly rare, an individual who 
doubt. Above all, it has to be assumed that the shareholders of newspaper companies like these were representative of active party workers. Within these limitations, however, certain broad conclusions become inescapable.

It was the skilled manual workers, the clerks and supervisory workers who were most attracted to the Labour movement, while at a national level there was a considerable leavening of professional people. Correspondingly, unskilled and, to a lesser extent, semiskilled manual workers were reluctant to be involved. This is largely what one would expect; despite the possibility of paying by convenient monthly instalments of $2 / 6 \mathrm{~d}$, the financial commitment would be onerous for the lower-paid workers. Yet this was a requirement for political participation at this time. A distinction must be drawn between members of a political party according to their personal level of activity, and a willingness to make a financial contribution to the official organ of the party must surely have been one important index of that activity. Two of the companies in this analysis, the Labour Leader Ltd. and the Woolwich company, traded on the reputations of their newspapers and were able to attract much more money than the third company, which grew out of an unique political situation and had nothing to offer shareholders but promises. But in every case the individuals who were prepared to make a considerable financial sacrifice must have been the very lifeblood of the political Labour movement in their localities.

The shareholder list of the Labour Leader Ltd. locates the dynamic of the ILP. Long after the party had made its first impact at Westminster, its reservoir remained in the North and North-West of England; the party might seek to be a national alternative to the great established political parties, but its areas of real strength and activity remained the traditional ones. To judge from the list it would appear, moreover, that the ILP drew more support from individual activists than from its own branches. There is little doubt that the structure of the ILP was fluid, with branches appearing and disappearing and revealing, in cases where they did remain in existence for a considerable time, an ebb and flow of activity. Indeed it might well be that the absorption of the ILP into the wider, more amorphous

is entered in two lists has given a different occupational description on each occasion; Pethick-Lawrence, for example, gives his occupation as "barrister" in the Woolwich Pioneer but "journalist" in the Labour Leader list. As evidence of possible omissions in the lists, Keir Hardie's will includes five shares in the Merthyr Pioneer valued at 2/6d, although Hardie's name does not appear among the listed shareholders. I am grateful to Dr Kenneth O. Morgan of The Queen's College, Oxford, for this information. 
Labour Party enabled it to conceal the reality that it was, in the last analysis, a very small party indeed.

\section{APPENDIX}

Labour Leader - Clubs, ILP branches, trade-union branches

Specified clubs and branches

No of shares

ILP (National, per J. R. MacDonald

Fulham ILP

Westminster ILP

Hammersmith ILP

ILP London

Stapleford ILP

Derby Socialist Society

Glossop ILP

North Manchester ILP

Preston ILP

Ashton ILP

Colne ILP

Gorton ILP

Oldham ILP

Nelson ILP

Warrington ILP

Macclesfield ILP

Hyde ILP

Huddersfield ILP

Brighouse ILP

West Bowling ILP, Bradford

Bradford ILP

Harrogate ILP

Ardsley ILP

Elland ILP, near Halifax

Shipley ILP

Doncaster ASRS

Stockton ILP

West Stanley ILP

Ashington ILP

Darlington ILP

Kingston ILP, Glasgow

Lochgelly ILP, Dunfermline

London
London
London
-
Nottinghamshire
Derbyshire
Lancashire
Lancashire
Lancashire
Lancashire
Lancashire
Lancashire
Lancashire
Cheshire
Cheshire
Yorkshire
Yorkshire

Yorkshire
Yorkshire
Yorkshire
Yorkshire
Yorkshire
Yorkshire
Durham
Durham
Northumberland
Durham
Scotland
Scotland


THE MEMBERSHIP OF THE INDEPENDENT LABOUR PARTY

Darvel ILP, Ayrshire

Scotland

Dennistoun ILP, Glasgow

Scotland

Larkhall ILP, Lanark

Scotland

Aberdare ILP

South Wales

Deptford Govt Works Fed.

London

Clubs represented through nominee (secretary etc.)

Derby Clarion Club

Stockport (no details)

Hull (no details)

Milnsbridge (no details)

Chester (no details)

Sunderland (trade-union branch)

Newport (trade-union branch)

Falkirk (trade-union branch)

Glasgow (Associated

Ironmoulders)

Workington (trade-union branch)

Dalston, Co. Durham (no details)

Bradford (club)

Manchester (trade-union branch)
J. Johnson, Secretary

T. A. Leonard, Secretary

T. A. Pierce, Secretary

D. Haigh, Secretary

Jackson Rob, Secretary

H. Lynas, Secretary

2

J. Twomy, Secretary

1

W. Marshall, Secretary

10

J. Jack, Secretary

10

P. Walls (Agent)

5

J. T. Harris, Secretary

H. Wilson

2

3

J. R. Clynes

1

Total number of shares

As $\%$ of share capital

Total number of institutions

As $\%$ of shareholders 